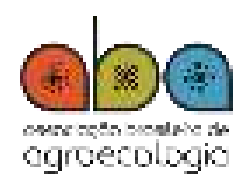

ISSN: $1980-9735$

\title{
COMUNIDADE EPIFÍTICA VASCULAR DO PARQUE ESTADUAL DA SERRA FURADA, SUL DE SANTA CATARINA
}

\author{
Vascular epiphytic community of the Serra Furada state park, south of Santa Catarina
}

Peterson Teodoro Padilha'.

\section{RESUMO}

O bioma Mata Atlântica é um conjunto complexo de ecossistemas tropicais com importância ímpar para abrigar uma parte representativa da biodiversidade brasileira e mundial. Os epífitos vasculares, uma categoria quase exclusiva das florestas tropicais, representam aproximadamente $10 \%$ de todas as plantas vasculares, podendo atingir mais de $25 \%$ das espécies em países com este tipo de formação. O objetivo deste estudo foi realizar levantamento florístico e estrutural de epífitos vasculares, incluindo a distribuição espacial, no Parque Estadual da Serra Furada (PESF), uma unidade de conservação localizada no sul do Estado de Santa Catarina, sul do Brasil. As espécies epifíticas foram amostradas em seis transectos estabelecidos ao longo de um gradiente de altitude no PESF. Em cada transecto foram demarcados cinco pontos quadrantes centrados, sendo consideradas as árvores mais próximas com DAP $\geq 10 \mathrm{~cm}$ como uma unidade amostral. Cada árvore foi dividida em duas zonas verticais, fuste e copa, onde a presença de epífitos foi registrada. Amostragem adicional foi realizada pelo método de caminhamento pela floresta, a fim de fornecer uma lista florística mais completa. Foram estimados, como parâmetros estruturais, as frequências absoluta e relativa em árvores, troncos e copas, e o valor de importância, calculados para fornecer uma ordenação das espécies em geral. A diversidade e equabilidade foram estimados pelos índices de Shannon e Pielou, respectivamente. A análise dos dados incluiu um teste qui-quadrado $\left(\chi^{2}\right)$ para comparar a frequência observada e a esperada em troncos e copas, uma análise de correlação para comparar o tamanho da árvore e a riqueza de epífitos, e uma análise de correspondência (AC) para detectar os padrões espaciais dos seis locais

${ }^{1}$ Mestre em Ciências Ambientais, UNESC

Dissertação de Mestrado defendida no Universidade do Extremo Sul Catarinense.

Programa de Pós-Graduação em Ciências Ambientais, Criciúma, 2014. $71 \mathrm{p}$.

Orientador: Vanilde Citadini Zanette

Ano de defesa: 2014

Recebido em: 30/10/2018

Aceito para publicação em: 24/11/2019

Correspondência para: peter@unesc.net amostrados. Como resultado, 115 espécies de epífitos vasculares foram registrados, 85 no levantamento fitossociológico e 30 no método de caminhamento na floresta. Orchidaceae foi a família mais rica, com 38 espécies, seguido de Bromeliaceae e Polypodiaceae, com 23 e 14 espécies, respectivamente. Os gêneros mais diversos, com cinco ou mais espécies, foram Vriesea (10), Epidendrum (6), Peperomia (5) e Tillandsia (5). As categorias ecológicas incluiram 94 espécies $(81,73 \%)$ de holoepífitos verdadeiros, enquanto que as estratégias de polinização e dispersão mais frequentes foram entomofilia $(66,66 \%)$ e anemocoria $(56,52 \%)$, respectivamente. A frequência e riqueza de espécies mostraram diferenças significativas entre fustes e copas, com valores mais elevados na copa, apontando como ambiente favorável. Os coeficientes de correlação mostraram aumento significativo da riqueza de espécies de acordo com a altura e DAP de forófitos. O índice de diversidade de Shannon da comunidade epifítica do PESF foi 3,81 e o índice de equabilidade de Pielou foi de 0,85. Estes valores indicam alta diversidade relativa quando comparados com outros estudos realizados no Sul do Brasil. A análise de correspondência indicou três grupos dos transectos de acordo com a altitude, mas a maioria provavelmente influenciada pelo efeito de borda e pela proximidade e distância de córregos. Embora o número de estudos com os epífitos vasculares venham crescendo, o presente estudo contribui efetivamente para o conhecimento desta forma de vida no sul de Santa Catarina, onde os epífitos têm sido quase sempre omitidos em estudos florísticos.

Palavras-Chave: Método Ponto-Quadrante. Riqueza. Forófito. Dossel. Floresta Ombrófila Densa Montana. 


\section{ABSTRACT}

The Atlantic Forest biome is a complex assemblage of tropical ecosystems with a unique importance for harboring a representative part of the Brazilian and global biodiversity. Vascular epiphytes, an almost exclusive category of tropical forests, represent approximately $10 \%$ of all vascular plants and may achieve more than $25 \%$ of the species in countries with this type of formation. The purpose of this study was to carry out a floristic and structural survey of vascular epiphytes, including spatial distribution, in the Serra Furada State Park (SFSP), a conservation unit located in the South of Santa Catarina State, Southern Brazil. Epiphytic species were sampled along seven transects established along an elevation gradient in the SFSP. Each transect comprised five point-centered quadrants, were the nearest tree with a $\mathrm{DBH} \geq 10 \mathrm{~cm}$ was considered as a sample unit. Each tree was further divided into two vertical zones, trunk and crown, where the presence of epiphytes was registered. Additional sampling was performed by a "walking method" across the forest, in order to provide a more complete floristic list. Absolute and relative frequency on trees, trunks and crowns were estimated as structural parameters, and an importance value was then calculated to provide a general species ordination. Diversity and evenness were estimated by the Shannon and Pielou indexes, respectively. Data analysis comprised a chi-square $\left(\chi^{2}\right)$ test to compare observed and expected frequency on trunks and crowns, a correlation analysis to compare tree size and epiphytic richness, and a correspondence analysis (CA) to detect the spatial patterns of the seven sampled transects. As a result, 115 species of vascular epiphytes were registered, 85 in the phytosociological survey and 30 in the additional walking method in the forest. Orchidaceae was the richest family, with 38 species, followed by Bromeliaceae and Polypodiaceae, with 23 and 14 species, respectively. The most diversified genera, with five or more species, were Vriesea (10), Epidendrum (6), Peperomia (5) and Tillandsia (5). Ecological categories included 94 species (81.73\%) of true epiphytes, while the most frequent pollination and dispersion strategies were entomophilous (66.66\%) and anemochorous (56.52\%), respectively. Species frequency and richness showed significant differences between trunks and crowns, reflecting higher values in the most favorable crown environment. Correlation coefficients showed a significant increase of species richness according to height and DBH of phorophytes. The Shannon index of diversity of the SFSP epiphytic community was 3.81 and the Pielou index of evenness was 0.85 . These values indicate a relative high diversity in comparison to other studies carried out in South Brazil. Correspondence analysis indicated three transect groups according to elevation, but most probably influenced by edge effect and stream proximity and distance. Although the number of studies concerning vascular epiphytes is increasing in recent times, the present study greatly contributes to the knowledge of this life-form in Southern Santa Catarina, where epiphytes have been mostly omitted in floristic studies.

Keywords: Point-Quadrat Method. Richness. Phorophyte. Canopy. Montana Dense Ombrophilous Forest. 